УДК 574,583: 556,55(477,64-2)

DOI https://doi.org/10.26661/2410-0943-2020-1-03

\title{
Особливості зростання та поширення мохоподібних в умовах міста Запоріжжя ${ }^{1}$
}

\author{
Домбровський К. О., Рильський О. Ф., Тунік А. Г. \\ ORCID: 0000-0001-6965-6989 \\ Запорізький наиіональний університет, Україна \\ dombrov1717@ukr.net
}

Ключові слова: бріофлора, деревні насадження, проективне покриття, форофіти, антропогенні комплекси, епіфіти.
У статті наведені результати досліджень бріофлори двох антропогенних комплексів (культурофітоценозу та селітебного ландшафту) міста Запоріжжя. Визначали місцезнаходження, частоту трапляння, проективне покриття та приуроченість бріофітів до конкретних форофітів на досліджених територіях. Досліджені особливості поширення епіфітних мохоподібних, виявлено їх субстратну приуроченість до найбільш поширених деревних порід. Виділено екологічні групи мохів, їх життєві форми, здійснено оцінку видів за ступенем урбанофільності. Встановлено, що видовий склад досліджених антропогенних комплексів міста представлений 11 видами мохоподібних, 3-поміж яких 7 видів $€$ епіфітними, інші види були виявлені на інших субстратах. Серед виявлених мохоподібних 2 види є рідкісними. Найбільша кількість епіфітних бріофітів виявлена на корі Ulmus minor Mill., Populus alba L. та Robinia pseudoacacia L. Середнє видове різноманіття епіфітів характерне для Acer negundo L. та Salix sp. Мохи досліджених територій міста Запоріжжя реалізують життєві стратегії бріоексплерентів піонерних та бріопатієнтів (екотопічних i ценотичних). Встановлений сильний позитивний кореляційний зв'язок між площею проективного покриття бріофітів та висотою їх розташування на форофітах. За результатами розрахунків індексу чистоти повітря, який коливався від 3,4 до 5,0, території селітебного ландшафту та культуроценозу відповідають середньо й слабко забрудненим бріоіндикаційним зонам відповідно. Порівняльний аналіз видового складу бріофітів двох антропогенних комплексів міста Запоріжжя показав високий коефіцієнт спорідненості $(0,60)$ бріофлор досліджених територій. Отже, видовий склад бріофітів цих територій $є$ досить однорідним. Отримані дані свідчать про значну роль епіфітних мохоподібних, які здатні швидко заселяти деревні насадження антропогенних комплексів міста, що є одним із чинників стабілізації урбоекосистеми.

\footnotetext{
1 Автори висловлюють слова вдячності професору кафедри ботаніки Херсонського державного університету Ходосовцеву О. Є. та доценту кафедри ботаніки Херсонського державного університету Загороднюк Н. В. за допомогу в перевірці та визначенні видів мохоподібних.
} 


\title{
Features of growth and distribution of mosses in the conditions of the Zaporizhzhia city
}

\author{
Dombrovskiy K. O., Rylsky A. F., Tunic A. G. \\ Zaporizhzhia National University, Ukraine
}

Key words: bryoflora, afforestation of trees, projective cover, phorophytes, anthropogenic complexes, epiphytes.

\begin{abstract}
The article presents the results of studies of bryoflora of two anthropogenic complexes (cultural phytocenosis and residential landscape) of Zaporizhzhia. Location, frequency, projective cover and confinement of bryophytes to specific phorophytes in the studied areas were determined. The distribution patterns of epiphytic mosses and their substrate preference to the most common tree species have been studied. The ecological groups of mosses, their life forms were identified and the species were evaluated by the degree of urbanophily. It was established that the species composition of the studied anthropogenic complexes of the city is represented by 11 species of bryophytes, among them 7 species of epiphytes, and the rest of the species were detected on other substrates. Among the detected bryophytes 2 species are rare. The largest number of epiphytic bryophytes is detected on the bark of Ulmus minor Mill., Populus alba L. and Robinia pseudoacacia L. The lower richness of epiphytes was found on Acer negundo L. and Salix sp. The strong positive correlation was revealed between the area of projective cover of bryophytes and their location height on the phorophytes. According to the calculations of the air purity index, which ranged from 3,4 to 5,0, the territories of the residential landscape and cultural cenosis corresponded to the medium and slightly contaminated areas, respectively, as follow to bryoindication. Comparative analysis of species composition of bryophytes of two anthropogenic complexes of the city of Zaporizhzhia showed high similarity index $(0,60)$ of bryoflora of the studied areas. So, the species composition of the bryophytes of these areas is quite homogeneous. The received data indicate the significant role of epiphytic bryophytes that are able to rapidly populate tree plantations of anthropogenic complexes of the city, which is one of the stabilization factors of the urban ecosystem.
\end{abstract}

\section{Вступ}

Місто Запоріжжя є одним з індустріальних центрів південно-східної частини України. У Запоріжжі майже в центрі міської забудови розташовані потужні підприємства чорної та кольорової металургії, хімічної промисловості, машинобудівного комплексу, зокрема й моторобудівної галузі. В історичному аспекті розвиток міста як урбоекосистеми відбувався таким чином, що великі промислові підприємства були розташовані дуже близько до селітебної забудови. Унаслідок такого техногенного навантаження в Запоріжжі склався несприятливий екологічний стан, який вимагав створення зелених насаджень, які частково компенсували би негативний антропогенний вплив на довкілля. Для вирішення цієї екологічної проблеми регулярно проводили озеленення міста здебільшого за рахунок висаджування інтродуцентної дендрофлори, враховуючи біолого-екологічні властивості порід дерев до умов місця зростання ${ }^{1}$.

В умовах антропогенно трансформованих територій урбоекосистеми форофіти є одним із поширених природних субстратів для розвитку мохоподібних. Мохоподібні широко використовуються в біоіндикаційних дослідженнях. За допомогою бріоіндикації можна оцінити екологічний стан міського середовища щодо впливу певних екологічних чинників ${ }^{2-5}$.

Дослідження багатьох бріологів ${ }^{6-8}$ показали, що структура мохоподібних та їх видове різноманіття можуть змінюватися внаслідок трансформації довкілля, наприклад урбанізованої території. Таким чином, мохоподібні можуть відображати урбанізацію у вигляді комплексного явища.

Бріофлора міських територій міста Запоріжжя, насамперед антропогенних комплексів, на сьогодні вивчена не досить. На тлі недостатньої вивченості бріофлори міста у бріологічному аспекті залишаються майже недослідженими урбанізовані території цієї урбоекосистеми. Деякі відомості про видове різноманіття мохоподібних Запорізької області наведені в низці робіт ${ }^{9-11}$ у разі проведення інвентаризації мохоподібних України.

Мета дослідження - встановити видовий склад та специфіку поширення мохоподібних в умовах деяких антропогенних комплексів міста Запо- 
ріжжя.

\section{Матеріали та методи}

Основою для цієї роботи стали результати дослідження оригінального гербарного матеріалу мохоподібних, зібраного авторами на територіях антропогенних комплексів м. Запоріжжя впродовж 2016-2018 рр. Згідно $з$ класифікацією ${ }^{7}$ нами була досліджена бріофлора двох антропогенних комплексів - культурофітоценозу (парк-пам'ятка садово-паркового мистецтва місцевого значення, Парк Енергетиків у Дніпровському районі) та селітебного ландшафту (район «Вознесенівського узвозу» - дамби вздовж центральної магістралі проспекту Соборного над частково засипаною балкою (Капустянський Яр), яка з'єднує Олександрівський і Вознесенівський райони міста).

3бір гербарних зразків проводився маршрутним методом на пробних ділянках, закладених у найбільш типових екотопах, заселених мохами. Дослідження епіфітів проводили на 12 пробних ділянках, на кожній із яких досліджували 10 порід листяних дерев незалежно від виду форофіту. Загалом було обстежено 120 екземплярів різних порід: Acer negundo L., Robinia pseudoacacia L., Populus alba L., Ulmus minor Mill., Salix sp., що найбільш поширені в зелених насадженнях міста. Стовбур дерева обстежували до висоти 2 м. Під час збору епіфітних та епілітних мохоподібних закладалися пробні ділянки розміром $0,1 \times 0,1$ м, під час дослідження нагрунтових екотопів - 0,5×0,5 м. Встановлювали субстратну й екотопічну приуроченість бріофітів, характер мохового покриву, його загальне проективне покриття. Проективне покриття мохоподібних вимірювали за існуючою методикою ${ }^{12}$ та оцінювали в балах (від 1 до 4) за відомою шкалою ${ }^{13}$. Епігейні та епіксильні види мохоподібних досліджували на 6 пробних ділянках, де зразки збирали з різних субстратів.

Гербарні зразки мохоподібних визначали за анатомічними та морфологічними ознаками методом світлової мікроскопії з використанням визначників $^{10,14}$. Частоту трапляння (зустрічальність) мохів розраховували за відношенням ділянок із певним видом до загальної кількості описаних ділянок (метод Раункієра). Для кількісної оцінки ступеня забруднення атмосферного повітря різних зон міста використовували індекс чистоти повітря (ГЧП $)^{15}$ :

$$
\text { ІЧП }=\sum_{i=1}^{n} \frac{Q_{i} f_{i}}{10},
$$

де: $Q_{i}-$ екологічний індекс певного виду (індекс токсифобності); $f_{i}$-комбінований індекс покриттятрапляння; $n$ - кількість видів.

Екологічний індекс виду $\left(Q_{i}\right)$ визначався за середнім значенням кількості видів, які трапля- лися поряд із цим видом на всіх пробних ділянках. Показник покриття-трапляння $\left(f_{i}\right)$ визначався візуально за 5-бальною шкалою: 1 - вид трапляється дуже рідко або $з$ дуже малим покриттям; 2 - вид трапляється рідко або з низьким покриттям; 3 - вид трапляється рідко або із середнім покриттям на деяких стовбурах; 4 - вид трапляється часто або $з$ високим покриттям на деяких стовбуpax; 5 - вид трапляється дуже часто або з дуже високим покриттям на більшості стовбурів.

За показниками індексу чистоти повітря виділяють певні бріоіндикаційні зони (ІЧП $=0,0-0,9-$ сильно забруднена зона, ІЧП = 1,0-2,6 - зона достатнього забруднення, ІЧП $=2,7-4,9-$ середньо забруднена зона, ІЧП = 5,0-10,0 - слабко забруднена зона, ІЧП > 10 - незабруднена зона).

Назви видів мохоподібних та їх таксономічне положення уточнені за «Чеклістом мохоподібних України» ${ }^{16}$. Для встановлення синантропних видів бріофлори використовували класифікацію, розроблену М.Ф. Бойко ${ }^{17}$.

Статистичні розрахунки проведено з використанням програмного забезпечення Statistica 10.0. Для обробки результатів використовували стандартні статистичні методики: середні величини обчислювали як середні арифметичні, варіабельність оцінювали за стандартним відхиленням. Критичний рівень статистичної значимості вважався достовірним за $\mathrm{p} \leq 0,05$. Перевірку нормальності розподілу проводили за допомогою тесту Шапіро-Вілка. Для оцінки зв'язку між площею проективного покриття епіфітів від висоти їх розташування використовували коефіцієнт рангової кореляції Спірмена (залежності відрізнялися від лінійних). Для порівняння бріофлор використовували коефіцієнт подібності Сьоренсена-Чекановського.

Анотований список мохоподібних

Amblystegium serpens (Hedw.) Shimp. - Тупокришник повзучий, на корі стовбурів дерев (Ulmus, Populus), гнилій деревині (Ulmus).

Bryum argenteum Hedw. - Головомох сріблястий, на бетонному бордюрі тротуарному (на його горизонтальній поверхні).

Bryum caespiticium Hedw. - Головомох дернистий, на прошарках грунту в заглибинах, дрібна форма (класичний Bryum caespiticium більший приблизно в 1,5 раза).

Bryum sp. - Головомох, на бетонному бордюрі тротуарному (на його горизонтальній поверхні).

Ceratodon purpureus (Hedw.) Brid. - Всюдник пурпуровий, на корі та біля основи стовбурів дерев (Ulmus, Robinia, Populus), гнилій деревині (Ulmus).

Grimmia pulvinata (Hedw.) Sm. - Гріммія подушкова, на бетонному бордюрі тротуарному (на його горизонтальній поверхні). 
Leskea polycarpa Hedw. - Льоскея багатоплода, на корі та біля основи стовбурів дерев (Ulmus, Robinia, Acer, Populus, Salix), гнилій деревині (Ulmus).

Orthotrichum patens Bruch ex Brid. - Прямоволосник відхилений, на корі стовбурів дерев (Ulmus, Robinia, Populus), вид включений до старої редакції Red Data Book of European Bryophyte ${ }^{18}$.

Orthotrichum pumilum Sw. - Прямоволосник карликовий, на корі стовбурів дерев (Ulmus, Robinia, Acer, Populus, Salix).

Orthotrichum speciosum Nees - Прямоволосник прекрасний, на корі стовбурів дерев (Ulmus, Robinia, Acer, Populus, Salix).

Ptychostomum capillare (Hedw.) Holyoak \& N. Pedersen (Bryum capillare Hedw.) - Сладкопродих волосконосний, на корі стовбурів дерев (Ulmus, Robinia, Populus).

Ptychostomum rubens (Mitt.) Holyoak \& N. Pedersen (Bryum rubens Mitt.) - Сладкопродих червонуватий, на прошарках грунту в заглибинах.

\section{Результати}

У зборах із досліджених ділянок антропогенних комплексів міста Запоріжжя нами ідентифіковано 11 видів мохоподібних (1 таксон не віднесено до виду), усі вони є звичайними представниками бріофлори степової зони України. 2 види - Orthotrichum patens та Ptychostomum capillare - належать до «регіонально рідкісних» (у межах Степової зони) мохоподібних ${ }^{10}$. На двох досліджених територіях мохи розподілені нерівномірно, спільні для них лише 5 видів: Amblystegium serpens, Orthotrichum pumilum, O. speciosum, Leskea polycarpa, Ptychostomum capillare (див. табл. 1).

У бріофлористичному комплексі культурофітоценозу (Парк Енергетиків) виявлено міс- цезростання 9 видів мохоподібних (1 таксон не був віднесений до виду). У складі дослідженої пам'ятки садово-паркового мистецтва місцевого значення мохоподібні представлені епіфітною, епілітною та епіксильною групами. Епіксильні мохові обростання сформувалися на субстраті рослинного походження - гнилій деревині (повалені стовбури Ulmus minor). Епілітні мохоподібні мешкають на бетонному бордюрі тротуарному біля асфальтових доріжок парку. Епіфітна група знайдена на корі живих дерев (стовбурах та основі стовбурів Robinia pseudoacacia, Ulmus minor, Acer negundo, Populus alba).

Інший бріофлористичний комплекс селітебного ландшафту сформувався в житловій забудові приватного сектору 3 достатньою кількістю зелених зон (під дамбою «Вознесенівський узвіз» 3 обох іiі сторін), де виявлено 7 видів. Більшість мохоподібних росте тут на території зелених зон, які представлені переважно різновіковими листяними деревами (Ulmus minor, Salix sp.). Решта мохоподібних оселяється на грунті. Так, на грунті траплялися 2 види - Ptychostomum rubens та Bryum caespiticium; останній вид $є$ високоактивним верхоплідним мохом та типовим для міських умов урбанофілом.

Вплив урбанізації на епіфітні мохоподібні проявляється у вигляді заміни аборигенних видів дерев породами дерев, які не притаманні цій місцевості (інтродуценти). Серед обстежених дерев найпоширенішими інтродуцентами м. Запоріжжя були Robinia pseudoacacia, Acer negundo, Populus alba. Перші два види дерев $є$ інвазивними рослинами, які здатні активно проникати у природні насадження. Поширення дерев роду Populus обмежується здебільшого селітебними ділянками міста.

Широке поширення в'яза та тополі на досліджених антропогенних комплексах урбоекосис-

Таблиця 1 - Мохоподібні антропогенних комплексів м. Запоріжжя

\begin{tabular}{|c|c|c|c|c|c|c|}
\hline \multirow{2}{*}{ Вид } & \multicolumn{2}{|c|}{ Місцезнаходження } & \multicolumn{5}{c|}{ Субстрати } \\
\cline { 2 - 7 } & I & II & S1 & S2 & S3 & S4 \\
\hline Amblystegium serpens & + & + & & + & + & + \\
\hline Bryum argenteum & + & & & & & + \\
\hline Bryum caespiticium & & + & + & & & + \\
\hline Bryum sp. & + & & & & & + \\
\hline Ceratodon purpureus & + & & & + & & + \\
\hline Grimmia pulvinata & + & & & & & + \\
\hline Leskea polycarpa & + & + & & + & & + \\
\hline Orthotrichum patens & + & & & + & & \\
\hline Orthotrichum pumilum & + & + & & + & & \\
\hline Orthotrichum speciosum & + & + & & + & & \\
\hline Ptychostomum capillare & + & + & & + & & \\
\hline Ptychostomum rubens & & + & + & & & \\
\hline
\end{tabular}

Примітки: I - Парк Енергетиків, II - район під дамбою «Вознесенівський узвіз»; S1 - грунт, S2 - кора дерев, S3 - гнила деревина, S4 - кам’янистий субстрат антропогенного походження 
теми зумовило високе видове різноманіття епіфітних мохоподібних на цих форофітах (див. табл. 2).

Результати дослідження показників проективного покриття бріофітів антропогенних комплексів м. Запоріжжя представлені в таблиці 3.

Високими показниками проективного покриття характеризувалися епіфіти Orthotrichum pumilum + Orthotrichum speciosum $(6,0-50,0 \%)$, Orthotrichum patens $(14,2-28,7 \%)$ та Amblystegium serpens + Ptychostomum capillare (4,3-24,9\%). Проективне покриття епігейних мохоподібних на досліджених пробних ділянках антропогенних комплексів було низьким і не перевищувало 1,5\%.

Для визначення індексу чистоти повітря досліджених ділянок нами були встановлені індекси токсикофобності, або екологічні індекси, мохоподібних шляхом визначення проективного покриття кожного виду моху в епіфітних обростаннях, які представлені в таблиці 4.

Для Парку Енергетиків ІЧП = 1,5 + 1,5 + 0,2 +
$0,3+0,4+0,6+0,5=5,0$, а для дамби «Вознесенівський узвіз» ІЧП $=0,8+0,8+0,8+0,5+0,5=3,4$. Результати кількісної оцінки ступеня забруднення атмосферного повітря антропогенних комплексів міста показали, що досліджені території належать до слабко забрудненої та середньо забрудненої бріоіндикаційних зон.

\section{Обговорення}

Мохи, виявлені в антропогенних комплексах, належать до 7 родів, 6 родин, 5 порядків, 1 класу, 1 відділу мохоподібних (Bryophyta). 3-поміж 11 видів мохів, виявлених на досліджених територіях, найбільшою кількістю видів представлені родини Bryaceae (4 види, 36,4\% видового різноманіття) та Orthotrichaceae (3 види, 27,3\%). Решта родин представлені 1 видом кожна.

В умовах міста Запоріжжя внаслідок континентальності клімату зі специфічним посушливим літом різноманіття екологічних ніш для мохоподібних обмежене. Серед мохоподібних на більшості

Таблиця 2 - Розподіл епіфітних мохів за видами форофітів

\begin{tabular}{|c|c|c|c|c|c|c|c|}
\hline \multirow{2}{*}{$\begin{array}{c}\text { Вид } \\
\text { (обстежено дерев) }\end{array}$} & \multirow{2}{*}{ Обростання (\%) } & \multirow{2}{*}{$\begin{array}{c}\text { Кількість } \\
\text { видів }\end{array}$} & \multicolumn{4}{|c|}{$\begin{array}{l}\text { Покриття } \\
\text { (в балах) }\end{array}$} & \multirow{2}{*}{ Середнє } \\
\cline { 5 - 7 } & & бріофітів & 1 & 2 & 3 & 4 & \\
\hline Ulmus minor (50) & $38(76,0)$ & 7 & - & 28 & 10 & - & 2,26 \\
\hline Populus alba (22) & $20(90,9)$ & 7 & - & 12 & 8 & - & 2,40 \\
\hline Robinia pseudoacacia (8) & $6(75,0)$ & 6 & - & - & 6 & - & 3,00 \\
\hline Acer negundo (4) & $2(50,0)$ & 3 & - & 2 & - & - & 2,00 \\
\hline Salix sp. (36) & $22(61,1)$ & 3 & - & 16 & 6 & - & 2,27 \\
\hline
\end{tabular}

Таблиця 3 - Середні показники проективного покриття (\%) бріофітів на досліджених ділянках м. Запоріжжя за 2016-2018 pp. ( $\overline{\boldsymbol{x}} \pm \mathrm{SD}, \mathrm{n} \geq 5)$

\begin{tabular}{|c|c|c|c|}
\hline \multirow{2}{*}{ Види } & \multirow{2}{*}{$\begin{array}{c}\text { Культуро- } \\
\text { фітоценоз, }\end{array}$} & \multicolumn{2}{|c|}{ Селітебний ландшафт } \\
\cline { 3 - 4 } & $2016 \mathrm{p}$. & $2017 \mathrm{p}$. & $2018 \mathrm{p}$. \\
\hline Orthotrichum pumilum + Orthotrichum speciosum & $24,46 \pm 16,69$ & $15,98 \pm 5,02$ & $16,94 \pm 15,34$ \\
\hline Amblystegium serpens + Ptychostomum capillare & $10,16 \pm 2,33$ & $4,66 \pm 0,30$ & $21,85 \pm 6,61$ \\
\hline Ptychostomum capillare + Ceratodon purpureus & - & - & $19,26 \pm 5,10$ \\
\hline Orthotrichum patens & $21,30 \pm 7,24$ & - & - \\
\hline Ptychostomum rubens & $0,47 \pm 0,03$ & $1,03 \pm 0,09$ & - \\
\hline Bryum caespiticium & - & $0,65 \pm 0,04$ & - \\
\hline Grimmia pulvinata + Bryum argenteum + Bryum sp. & $16,50 \pm 0,08$ & - & - \\
\hline Amblystegium serpens + Leskea polycarpa & $0,49 \pm 0,05$ & - & - \\
\hline
\end{tabular}

Таблиця 4 - Індекси токсикофобності видів мохоподібних м. Запоріжжя

\begin{tabular}{|c|c|c|c|}
\hline № & Вид & $Q_{i}$, & $Q_{i}$, \\
з/п & Парк Енергетиків & дамба «Вознесенівський узвіз» \\
\hline 1 & Orthotrichum pumilum & 5,3 & 4,3 \\
\hline 2 & Orthotrichum speciosum & 5,3 & 4,3 \\
\hline 3 & Leskea polycarpa & 5,3 & 5,3 \\
\hline 4 & Amblystegium serpens & 2,0 & 5,0 \\
\hline 5 & Ptychostomum capillare & 2,0 & \\
\hline 6 & Orthotrichum patens & 2,5 & \\
\hline 7 & Ceratodon purpureus & 2,5 & \\
\hline
\end{tabular}


досліджених ділянкок антропогенних комплексів міста переважають види мезоксерофіти (70\%) епіфіти, які здатні витримувати низьку температуру й дефіцит вологи. Для досліджених ділянок м. Запоріжжя характерні антропофільні, урбанофільні види мохоподібних, які є високорезистентними до забруднення атмосферного повітря (зокрема, Leskea polycarpa, Ceratodon purpureus, Grimmia pulvinata, Ptychostomum capillare, Bryum caespiticium, B. argenteum), помірні урбанофіли Orthotrichum pumilum, O. speciosum та крайній урбанофіл Amblystegium serpens. Ці види бріофітів характерні для антропогенних бріофлор інших міст України ${ }^{19}$.

На корі стовбурів та у прикомлевій частині стовбура листяних порід пов'язане обростання 7 видів мохоподібних. На корі Populus alba виявлено місцезростання всіх 7 видів мохоподібних. Тут утворюються обростання мохоподібних, які представлені 2-3 видами. У формуванні обростань були виявлені такі мохові угруповання: Orthotrichum pumilum + Orthotrichum speciosum 3 домішкою Leskea polycarpa (проективне покриття 18-50\%); Amblystegium serpens + Ptychostomum capillare приблизно в рівному співвідношенні (покриття до 13\%); Orthotrichum patens 3 домішками стерильних екземплярів Ptychostomum capillare, Ceratodon purpureus (проективне покриття не перевищує 14\%).

Склад i структура обростань мохоподібних, зібраних на стовбурах Ulmus minor (покриття 4-21\%), Robinia pseudoacacia (покриття 28-32\%), Salix sp. (покриття 18-22\%) та Acer negundo (покриття до 8\%), подібні до мохових угруповань на тополях. У межах досліджених територій нами не було виявлено чітко виражену видоспецифічність мохових угруповань, віднесених до окремих видів форофітів. Найкраще виражені епіфітні мохові обростання були виявлені на таких видах дерев, як Populus alba (90,9\%), Ulmus minor (76,0\%), Robinia pseudoacacia $(75,0 \%)$.

За результатами проведеного дослідження на території обстежених ділянок антропогенних комплексів виявлено 3 життєві форми мохоподібних. У дослідженій групі мохоподібних переважають види із життєвою формою щільної дернини (Ceratodon purpureus, Ptychostomum capillare, Bryum caespiticium), що становлять 55\% від загальної кількості бріофітів. Мохоподібні із життєвою формою подушкоподібної дернини та плаского килима становлять $27 \%$ та $18 \%$ відповідно.

Важливою характеристикою окремих видів мохоподібних є тип життєвої стратегії. Розподіл мохоподібних за групами відповідно до типу реалізованої ними життєвої стратегії був таким:

- переважаючою групою виявилися піонерні бріоексплеренти (6 видів, 54,5\%), що схильні захоплювати різноманітні субстрати, які утворилися в умовах урбоекосистеми. До цієї групи належать Ceratodon purpureus, Ptychostomum capillare, Bryum caespiticium, B. argenteum, Grimmia pulvinata, Ptychostomum rubens. Перші чотири види належать до групи особливо активних (ценоекотопічно) мохоподібних;

- екотопічні бріопатієнти (4 види, 36,4\%) були представлені переважно епіфітними бріопатіентами (рід Orthotrichum);

- серед групи ценотичних бріопатієнтів був виявлений один вид мохоподібних - Leskea polycarpa.

За відношенням до освітлення в мохоподібних досліджених антропогенних комплексах міста переважають геліофіти та сциофіти - по 4 види відповідно (разом становлять 73\% від загальної кількості бріофітів). Геліосциофіти представлені 3 видами (27\%).

У бріофлорі досліджених територій м. Запоріжжя кількість однодомних і дводомних видів мохоподібних приблизно однакова 3 невеликим переважанням однодомних, а саме: 6 видів $(54,5 \%)$ та 5 видів $(45,5 \%)$.

На досліджених територіях, що зазнали тією чи іншою мірою антропогенних змін, було виявлено синантропну (апофітну) фракцію мохоподібних, а саме 9 видів $(81,8 \%)$ мохів. 8 видів синантропних мохоподібних (72,7\%) - геміапофіти, 1 вид $(9,1 \%)$ - евентапофіт.

Унаслідок порівняння видового складу мохоподібних двох ділянок антропогенних комплексів міста за коефіцієнтом Сьоренсена-Чекановського було з'ясовано, що коефіцієнт спорідненості видового складу бріофітних угруповань був високим $(0,60)$. Отже, видовий склад бріофітів цих територій урбоекосистеми є досить однорідним. Поряд із типовими для антропогенних ландшафтів тут спостерігаються відносно рідкісні види мохоподібних (Orthotrichum patens, Ptychostomum capillare), які у степовій зоні спорадично трапляються у природних угрупованнях. Пояснюється це різноманітністю екотопів у досліджених ділянках.

Найбільша кількість мохоподібних росте на корі стовбурів вищих рослин (7 видів), до інших субстратів віднесені 2-3 види. Отже, збільшення площ деревних насаджень у межах антропогенних комплексів міста автоматично буде збільшувати їх біорізноманіття.

За індексом чистоти повітря $(5,0)$ Парк Енергетиків належить до слабко забрудненої бріоіндикаційної зони. Значення ІЧП під дамбою «Вознесенівський узвіз» $(3,4)$ відповідало зоні середнього забруднення.

Площа проективного покриття епіфітних мохових обростань і висота їх розташування на обстежених форофітах досить добре корелюють: 
коефіцієнт кореляції Спірмена, розрахований для дослідних ділянок селітебного ландшафту міста у 2018 р., становить 0,78. При цьому високі значення загального проективного покриття забезпечувалися п'ятьма найпоширенішими видами бріофітів.

\section{Висновки}

Бріофлора двох антропогенних комплексів (культурофітоценозу та селітебного ландшафту) м. Запоріжжя включає 11 видів мохоподібних, що заселяють чотири різні типи екотопів.

Структурний аналіз бріофлори досліджених територій міста показав, що в угрупованнях мохоподібних домінують представники родин Bryaceae та Orthotrichaceae, види життєвих форм дернини щільної, екологічних груп мезоксерофітів, геліофітів і сциофітів; також встановлено переважання синантропних видів $(81,8 \%)$ над індигенофітами. Особливою рисою, що характеризує цю частину бріофлори антропогенних комплексів м. Запоріжжя, $є$ збільшення частки антропофільних, урбанофільних видів, які є стійкими до забруднення атмосферного повітря, а також майже однакова кількість одно- й дводомних видів.

Мохи досліджених територій м. Запоріжжя реалізують життєві стратегії бріоексплерентів піонерних та бріопатієнтів (екотопічних і ценотичних). Видовий склад бріофітів двох антропогенних комплексів міста є досить одноманітним, про що свідчить високий коефіцієнт спорідненості Сьоренсена-Чекановського.

За індексом чистоти повітря встановлено, що територія культурофітоценозу характеризується як слабко забруднена зона, а ділянка селітебного ландшафту відповідає середньо забрудненій бріоіндикаційній зоні.

Предметом наших подальших досліджень стане інвентаризація списків мохоподібних в об'єктах природно-заповідного фонду, а саме парків-пам'яток садово-паркового мистецтва. Ці дослідження $€$ важливою частиною моніторингу бріофлор у межах антропогенних комплексів міста Запоріжжя.

\section{Література}

(1) Яловенко А.С., Бессонова В.П. Характеристика паркових зон міста Запоріжжя. Питання біоіндикаиії та екологіï 2010, 15 (2), 71-79. URL: https://doi.org/10.1017/CBO9781107415324.004.

(2) Бойко М.Ф. Характеристика мохоподібних як індикаторів стану навколишнього середовища. Чорноморський ботанічний журнал 2010, 6 (1), 35-40.

(3) Daly, G.T. Bryophyte and in Lichen Indicators New of Air Pollution Christchurch, Zealand. Proc. New Zeal. Ecol. Soc. 1970, 17, 70-79.

(4) Govindapyari, H.; Leleeka, M.; Nivedita, M.; Uniyal, P. Bryophytes: Indicators and Monitoring Agents of Pollution. NeBIO 2010, 1 (1), 35-41.

(5) Pescott, O.L.; Simkin, J.M.; August, T.A.; Randle, Z.; Dore, A.J.; Botham, M.S. Air Pollution and Its Effects on Lichens, Bryophytes, and Lichen-Feeding Lepidoptera: Review and Evidence from Biological Records. Biol. J. Linn. Soc. 2015, 115 (3), 611-635. URL: https://doi.org/10.1111/bij.12541.

(6) Барсуков О.О. Епіфітні мохоподібні м. Харкова. Украйнський ботанічний журнал 2014, 71 (2), 214-222.

(7) Глухов О.3. Індикація техногенного забруднення середовища із застосуванням мохів. Промышиенная ботаника 2007, 7, 3-10.

(8) Рыковский Г.Ф. Концептуальная модель происхождения и эволюции мохообразных. 2014, с. 560.

(9) Бойко М.Ф. Мохообразные в иенозах Степной зоны Европы: монография, Херсон, Айлант; 1999.

(10) Бойко М.Ф. Мохоподібні Степної зони Украйни: монографія; Айлант: Херсон, 2009.

(11) Лазаренко А.С. Определитель лиственных мхов Украины, АН УССР: К. 1955, с. 467.

(12) Улычна К.О., Гапон С.В. К методике изучения эпифитных моховых обростаний. Проблемы бриологии в СССР; 1989; с. 201-206.

(13) Барсуков О.О. Бріофлора урбанізованих територій Харківської області. Чорноморський ботанічний журнал 2014, 10 (3), 305-321. URL: https://doi.org/10.14255/2308-9628/14.103/3.

(14) Игнатов М.С. Флора мхов средней части европейской России. T. 1 Sphagnaceae-Hedwigiaceae, KMK: M.; 2003.

(15) Мамчур. 3. Бріоіндикація забруднення повітря у місті Львові та на його околицях. Вісник Львівського ун-ту. Сер. біологічна 2005, 40, 59-67.

(16) Бойко М.Ф. Чекліст мохоподібних Украӥни; Айлант: Херсон, 2008.

(17) Бойко М.Ф. Синантропна бріофлора України. Чорноморський ботанічний журнал 2005, 1 (№ 2), $24-32$.

(18) Red Data Book of European Bryophytes; Trondheim, 1995. URL: https://doi.org/10.2307/3244314.

(19) Мамчур. 3. Урбанофільні Епіфітні Мохи у м. Львові. Вісник Львівського ун-ту. Сер. біологічна. 2010, 54, 115-122. 